\title{
Exploring the Important Factors of Informal Science Education Program of Youth in Poverty: A Case Study of Informal Earth Science Education Program in the U.S.
}

\author{
Younkyeong Nam* \\ Department of Curriculum and Instruction, University of Minnesota, Minnesota, 55108, USA
}

\begin{abstract}
There has been increasing evidence of the positive effects in informal science programs to promote the youths' positive development. However, relatively a small number of informal science programs target specific student populations such as youth in poverty with little research done about the important program factors. This case study presents an exemplary informal science education program (focusing on Earth Science Education or more specifically, water in urban environments) for youth in poverty in a midwest city of the United States. This study explored the most important characteristics of the program that could lead to positive development for the youth. Through a number of observations of the program and interviews with the participants, this study employs inductive and interpretive research methods. Findings show that the program managers' beliefs about the youths' knowledge and experiences, their relationship building skills, and their cooperative work are very important. A concrete mission for the program and structured institutional support to hire the youth as paid museum staff are also important in assuming their responsibility and building identity as an active social member.
\end{abstract}

Keywords: Informal science education, Youth development, Out-of-school science programs for youth in poverty

\section{Introduction}

Quality and effectiveness for out-of- school science education programs are very important to encourage more youth to learn science, to pursue a career in science, and to make science education more relevant to youth (Dierking, 2007; Jung et al., 1995; Jung et al., 2009; Resnick, 1987). There has been increasing evidence about the positive effects of informal science programs on youths' critical thinking skills, behaviors, and academic pursuits (Kim et al., 2009; Koke and Dierking, 2007). However, most of the youth participants of informal science education programs are still from families of higher socioeconomic status (SES) (Larson, 2000). Note that programs for youths from poor communities have increased considerably, while there are relatively a few informal science education programs specifically designed to consider youth participants' socio-cultural context.

\footnotetext{
*Corresponding author: namxx020@umn.edu

Tel: +1-651-587-7773

Fax: +1-612-626-0993
}

The studies about informal science program factors that are related to positive youth development (e.g. Dierking, 2007; Koke and Dierking, 2007) are not capable of examining do not examine in detail the most critical factor - youth participants' socio-cultural characteristics and how they interact with the programs. Moreover, most of the studies about informal science education programs do not explicitly address the correlations between positive outcomes and sociocultural contexts of the youth participants. In other words, the critical informal science education factors for youths' positive development investigated addressed in these studies may not work in a context where most of the youth participants have a low socioeconomic status. Based on a review of statistical research about informal science educations' effects on youth positive development, Larson (2000) also argued, if we can control the youth participants' socio-cultural factor such as SES, the significance of the positive outcomes will be reduced in strength.

Effective informal science education for underrepresented groups can be one of the answers to solve the inequity problems in science education (Fadigan 
and Hammrich, 2004). Unfortunately, the current body of literature on informal science education is not sufficient to inform us of the important program factors necessary for successful youth science programs that target youth in poverty. Therefore, detailed analysis of an exemplary informal science education program for youth in poverty is a necessary approach to understand the important characteristics of program participant. This case study focused on presents an exemplary informal science education program for youth in poverty in a Midwest city in the United States. In this study, I explored the most important characteristics that could lead to positive development for youth in poverty. The specific questions for this study include:

(1) What characteristics are important for the program manager to embody in order to create an effective informal science education program for youth in poverty?

(2) What characteristics are important in order to create an effective informal science education program for youth in poverty?

\section{Literature Review: Informal Science Education Program Factors}

There are many studies that show evidence of positive youth development in informal science education programs such as critical thinking skills, academic pursuits, and social skills (e.g. Baum et al., 2000; Beane, 2000). Critical factors correlated with these findings are supportive adults, positive relationships with peers, activities that are meaningfully related to a student's life, the degree of the integration to an institution's mission, and connections to community programs (e.g. Dierking, 2007; Koke and Dierking, 2007). These studies also show that youths' positive development in an informal science education program is not only related to the program manager's leadership in developing strong relationships with youth participants but also external program characteristics, such as the program's mission, goals and institutional support (Dierking, 2007; Fadigan and
Hammrich, 2004).

There is increasing evidence that the most critical factors correlated with positive effects of most informal science programs is supportive adults who worked hard to establish positive relationships with the youth (Dubois and Neville, 1997; Dierking, 2007). The program manager's role in informal science education programs is especially important for youth from poverty because they often need an adult for additional quality science learning (Benard, 1992; Fadigan and Hammrich, 2004). Most low income families cannot support quality science education resources for their kids, like quality books, afterschool programs, and out-of-school science programs, and as a result, these kids are more likely to fail to pursue higher education in science related degrees (Benard, 1992). Program managers in youth science education programs not only play an important role model as a science teacher or a scientist, but they also have a great potential to influence the youth to enter science careers through their attitudes, encouragement, expectations, resources, teaching methods, and classroom materials (Fadigan and Hammrich, 2004). However, there has been a lack of research to suggest the important characteristics for program managers, especially in science programs for youth in poverty.

In general, studies about mentoring youth suggest two important factors that help to build strong relationships; continuity and consistency in mentoryouth contact (i.e, at least once-a- week) as well as strong feelings of personal closeness (Dubois and Neville, 1997). For the programs for youth in poverty, Benard (1992) suggests more specific factors that could build strong relationships between adult and urban youth participants, personalized attention and care, access to cultural and vocational resources, positive and high expectations, reciprocity and youth participation, and sustained personal commitment from the adult. Beyond the commitment of consistent contact, Benard (1992) also points out that the program manager's skills and beliefs about mentoring urban youth are important in making strong relationships with urban youth. According to Benard (1992), 
supporting youth's emotions, providing information about vocational opportunities, and managing their behaviors for accomplishing the program objectives are important skills that a program manager must have in order to build successful relationships.

In addition to the importance of supportive adults (program managers), an informal science education program's mission determines the overall objectives of the program and family and community involvement, and consequently affects the program manager's pedagogical approach. Institutional support is also important for the success of an informal science education program. It determines availability of science educational resources and facilities and eventually affects the youth's academic achievements (Baum et al., 2000; Dierking, 2007; Koke and Dierking, 2007). The program's mission and institutional support are important external factors that could shape the overall program's quality and outcome.

\section{Methodology}

This study is qualitative and interpretive in nature (Miles and Huberman, 1994). It employs a case study (Merriam, 1998) in which the informal science education program presents a single case giving a unique example of successful informal science program for youth in poverty.

\section{Program context}

The program is an out-of-school youth science program at a youth science center of a science museum located in a big mid-west city near the Mississippi River. Over its 12 years, the programs in the youth science center have become one of the most admired museum-based youth programs in the Unites States. These programs have also been widely acknowledged as a leader among museum youth programs (Nelson and Schreiber, 2009). The program was created in 1996 to give youth from traditionally underrepresented populations a professional opportunity working in the science museum, learning science, and teaching science at the museum or one of its outreach sites. The youth in the program help museum staff build exhibitions, teach visitors at one of the assigned sites in the museum, research the STEM (Science, Technology, Engineering, and Mathematics) field, create lesson plans for outreach programs, and teach younger students in the outreach programs. Currently, approximately100 youth between the ages of 12-18 years old work as part of the program team. They mostly attend inner city middle and high schools and $75 \%$ of them qualify for free and reduced lunch. $60 \%$ of the participants are girls.

The youth participants work in one of the senior level groups in the youth science center. The youth group is composed of 8 to 12 junior and senior high school students who are led by the program manager. The youth group began in 2003 through funding from a National Science Foundation Science and Technology Center that studies earth surface dynamics. The team provides public outreach activities based on the work of the national science center and earth science related topics. As a result of participating in the youth group, participants learn about earth-surface processes, specifically those related to water resources, and the role humans play in affecting the processes. They also personally develop and strengthen their teaching skills so they can educate the public (museum visitors and school outreach groups) and outreach programs that teach younger students ( $\mathrm{K}$ through $4^{\text {th }}$ grade) from poor communities. They also become aware of STEM careers and explore educational and professional opportunities in these fields. The primary activities of the youth group are developing and sharing waterbased earth-surface process activities with the public. The participants visit after-school program sites during the winter to share activities with elementary students. During the summer, the youth group facilitates activities in the museum's outdoor science park. Over 2,000 museum visitors interact with the youth group's activities each summer.

\section{Participants}

This study is based on the lives of six youth from 
poverty-stricken communities and the program manager who leads the group of the students. The group is called the Earth Science Crew. They are all urban high school students (11-12 $2^{\text {th }}$ grade). Out of six students, two are male and four are female. One male student is white and the rest are students of color. All of the students were born in the United States. Four of them are from immigrant families. In the following paragraph, I briefly describe the program manager's background.

The program manager is in his late 20's and is a Caucasian male. He has been working for the program for three years and his educational background is in environmental science. The main role of the program manager is to support the youth team members in improving their scientific knowledge and skills in STEM (Science Technology, Engineering, and Mathematics) as well as engaging youth in the professional opportunities of teaching STEM related concepts. The program manager also helps the youths to pursue higher education by finding and sharing college entrance information and financial support such as scholarships and grants.

\section{Data collection}

The data for this study comes from two sources: 1) intensive observations from fall 2009 to spring 2010 at the youth science center, field trips to several sites along the Mississippi River, and a field trip to a Water Treatment Plant in the city, and 2) taped and transcribed interviews and informal conversations collected from fall 2009 to spring 2010 with the program manager and the youth participants.

\section{Data analysis}

Qualitative and inductive data analysis methods (Pattern, 2002) were used to analyze the interview and classroom observation data. However, data on classroom observations served mainly for triangulation purposes to support the validity of the common themes. Qualitative analysis proceeded with initial descriptive codes being assigned to the interview transcripts. Related codes were then grouped according to common themes. The common themes were; program manager's leadership, program's mission, and institutional supports. The coding was conducted independently by two other researchers, including the author. The inter-rater reliability in this coding was $86 \%$. The interpretation of the classroom observation descriptions were also cross-examined with the program manager. This written data analysis focused on looking for variability and consistency in what the youths said about their experience in the program and the program factors that affect positive youth development.

\section{Findings}

This study was designed to identify characteristics of an exemplary informal science program that produces positive development for youth. First, I address the most important factor, the program manager's leadership by focusing on his beliefs and skills in building strong relationships with the youth participants. Then I address the program's characteristics by focusing on the program's mission and institutional support in relations to the program manager's pedagogical approach.

\section{Program manager's leadership as a supportive adult and mentor}

The program manager believes that the most important factor for the success of the program is building strong relationships between him and the youth participants as well as the strong relationship between the youth and their peers in the program. He tries to create an atmosphere where the youth feel accepted and respected. For example, the program manager conducts group time called 'High and Low', in which each person shares personal issues of their everyday life with him and the other youth. The youth share a 'high', which could be an exciting event that they enjoyed or that made them excited at school or in their home. A 'low' is the opposite and could be a bad grade, sickness, or anything else that makes them feel bad or frustrated. The program manager 
participates in 'High and Low' not as a leader, but as another participant by sharing his own life. Through the experience sharing and hearing their peers concerns and issues in their everyday lives, the youth build a sense of closeness. The 'High and Low' time shows the program manager's careful consideration to build strong relationships between the youth as well as the relationship between him and the youth. The 'High and Low' time is not just for sharing their everyday life but also for sharing their feelings and giving and receiving emotional support. The following quote from a youth participant shows how much she built strong relationships with other members of the program.

"It's really fun to have peers with you. Understanding what you're going through and they're going through.... You can be open with them.... it's good to be open with them, because they understand, and I really like to be open with them... I trust them a lot... I'm never like - like I trust all of them, they're my co-workers, that's my team... and we tell each other everything we know."

The program manager also believes that urban youth's different backgrounds, knowledge, and experiences from their everyday life are valuable. He values their teaching experience in informal settings as well as from their everyday life experiences like talking and teaching scientific concepts to their friends at school, teaching younger kids in their church or community, and teaching younger siblings at their home. More importantly, he expects that urban youth can choose more relevant topics for younger kids in urban areas because they grew up in the same place and share similar norms and interests. In other words, the program manager does not see an each youth's different personal characteristics and their funds of knowledge from their home as an obstacle for strong team performance but instead as a good source to make a strong team performance.

"I do like to have a variety of levels of experiences and ability cause you can look to those people who have more strong connections to science and higher academic achievement to help pull up those youth who are not good at science, so they acted as role models for them. Maybe you know who aren't successful in those area, see work along sides somebody who has more success in those area. You know as well I hire youth who have more advanced interpersonal skills who may be aren't in science area because then personality wise they can help people who are less confident and more shy develop those skills...sharing their skills. Somebody who is more extraverted but has less science skills does not feel they are inferior to this person who is good at science because they have some skills they could work on."

The program manager also believes that cooperative working skills are the most important thing for youth to accomplish in the program and which consequently makes them feel successful. To have a strong team performance, he also encouraged the youth to respect individual merits such as social skills, interests and scientific knowledge. During the process of choosing the teaching topics and developing ideas for activities, the program manager demonstrates his respect to each youth's opinion and knowledge as a role model. $\mathrm{He}$ also supports the youth in using their different personality and characteristics for their work and helps them to focus on their merits. For example, he encourages the youths who have more scientific knowledge to help other youth who have less knowledge than them. He also encourages those who have more social skills to lead a discussion. $\mathrm{He}$ always prepares activities and opportunities for the youth to work cooperatively.

The program manager is a mentor teacher to help the youth (beginning teachers) think about the purpose of teaching, alternative strategies, classroom management issues, and safety of scientific experiments. He also supported the group in finding teaching resources or materials that are available at the youth science center. For example, before the youth started the lesson planning, the program manager prepared two field trips to urban areas near the Mississippi River. He thought that these experiences might invite more youth to learn more scientific knowledge about the water we drink as well as to make the water 
knowledge they have learned at their school more meaningful to them. He helps the youth connect the topics of the program; urban water resource and water quality to their everyday life and to learn scientific knowledge that is meaningful for them.

In summary, the program manager respects the youth's experience and knowledge from their home and culture. $\mathrm{He}$ is creates a cooperative work community where they can share their experience and knowledge. His leadership to create an atmosphere and community that respects their own knowledge and choices also help the group members to build strong relationships. His leadership and pedagogical orientation cannot be isolated from the program's mission and pedagogical orientation. In the following I describe how the program's mission shapes the program as relevant to the youth from poverty.

\section{The program mission}

The program manager's belief about building strong relationships and a respectful atmosphere coincides with the program's mission. He mentions that the program's mission emphasizes the importance of building strong relationships between participants and programs by creating an atmosphere in which they are accepted and respected. The program makes a great point of building an open-minded atmosphere for urban youth who have different cultural and linguistic backgrounds and family problems.

The program's mission not only affects the program manager's pedagogical orientation but also how the program manager designs and manages the physical spaces and facilities of the program and facilities. The program space was organized and designed so that the youth can come anytime and meet their peers and program managers. The space includes couches and tables for talking with peers; sinks and a refrigerator for eating and keeping their own snacks; computers for research, checking e-mail and downloading music files during the break; educational resources such as books and science equipment; and a posting space with information about college scholarships and grant opportunities. The facilities are oriented to support the youth's scientific knowledge, relationships between the program manager and each other, and their academic pursuits in STEM filed.

The most important factor in the success of the program is that the program offers the youth the opportunity of community service which makes them proud of themselves as an active social member. The community service includes teaching museum visitors during the summer and teaching earth science for elementary students at afterschool programs at community centers. Through the community service and teaching experience, urban youth can develop their identity as an active social member.

I found that the youth believed that they positively affected their learners' (museum visitors and younger students at afterschool programs) scientific knowledge and awareness of urban water quality and stewardship about environmental problems. The following quote shows one of the youth's thoughts about her experience teaching younger kids in an outreach program.

\footnotetext{
"When we started doing outreaches, I realized working with kids is fun and easy in a way. The coolest thing is just basically seeing children, how they develop more. I think it is pretty fun...It was interesting seeing the children, for example if we ask them about water, it is interesting hearing difference ideas from children."
}

The community service opportunities also offer a unique experience in which the youth use knowledge from their everyday life experiences. Through the process of teaching the youth can share their funds of knowledge from their own experience of teaching their own siblings and at other community services such as Sunday School at church. They learn that knowledge from their everyday life is valuable. They also feel strongly that they contribute to their community by teaching younger students who are in a similar context to them in terms of living in an urban area, having low family support, and low socioeconomic status. The good characteristics of the program play an important role in making urban youth more responsible, more open-minded to their peers, as 
well as helping them to develop more professional skills.

\section{The science museum: institutional support}

The institutional support from the museum helps urban youth to accomplish their responsibilities through an employment opportunity. The employment opportunity is very important for urban youth in poverty because some of them give financial support to their family. Paying them makes the program more meaningful and helps them to develop their identity as an employee. The following quote shows how one of the youths expressed her experience of being responsible in this program.

"I think responsibility is a big thing, that's my first job. I used to work at a mall, at the food court. I was passing out samples.... Then when I came here, it was a big change. I never expected learning about responsibility. I think it's my big task, as Tom (the program manager) mentioned, we got to come up with ideas about how to learn in a way. That is a big responsibility putting in our hands what the kids are going to learn."

In a larger institutional context, the museum's support makes the implementation of the program's mission possible. The youths' working experience in the Earth Science Crew is based on a yearlong process of four chronological cycles. They work with museum visitors during the summer, develop lesson plans for outreach programs during the fall, co-teach using the lesson plans during the winter, and reflect on the experience during the spring. After the yearlong support from the museum, they could continue to reflect on their learning and teaching as well as build strong relationships with their peers.

\section{Conclusion and Implications}

There is no doubt that the program manager's pedagogical orientation is affected by the program characteristics, curriculum, activities, and philosophy. However, he also has his own pedagogical ideas that are unique and independent to the program itself.
First, I tried to categorize his beliefs and skills in building strong relationships with the youth in poverty. The program manager's belief about the youth's personal experience and knowledge that they can bring to the other youths and to the team performance makes his pedagogical practice more relevant. For example, he expects that the youth would have more relevant knowledge and experience for teaching a water unit to younger students who are from similar cultural backgrounds. He also allows the youth to teach other peers and accepts the science topics the youth participants choose for the outreach program.

More importantly, the program manager has built strong relationships with the youth by demonstrating his trust and expectations towards their ability and skills for cooperative work as well as by offering opportunities to make them feel strong personal closeness with each other. This finding also supports the findings from other studies (e.g. Dubois and Neville, 1997). Furthermore, the program manager's pedagogical beliefs and skills makes each youth's funds of knowledge valuable in the working context and helps them to maximize their funds of knowledge in positive ways. This finding echos the findings from other literature saying that the critical factors correlated with positive effects of most informal science programs are supportive adults with high expectations who worked hard to establish positive relationships with them (Dubois and Neville, 1997; Koke and Dierking, 2007; Fadigan and Hammrich, 2004) and curriculum and activities that were interesting, personalized and meaningfully related to their daily lives (Fusco, 2001; Gonzalez, 2005; Hammond, 2001; King et al., 2001).

I also found that the program's mission and institutional support is also an important factor along with the program manager's beliefs and skills. Encouraging urban youth to be an active member of a community through informal science education is very important for youth in poverty. However, without a concrete program mission for helping the youth from poverty and structured institutional support, it is impossible to offer youth the real experience of being 
hired as active social members such as teachers and museum staff in this program. The experience of working as real staff in the museum helps the youth to develop their sense of responsibility and their social identity.

This study implies that the program manager's beliefs about urban students skills to develop curriculum and be a teacher were important to empower urban youth to be more active and responsible social members. There have been many studies that suggest that this is what makes the most effective teachers for youth in poverty or in poor urban environments (e.g. Atwater, 1995; Gess-Newsome and Southerland, 2000; Ladson-Billings, 1995; Murrell, 2000; Sleeter, 2001; Villegas and Lucas, 2002). This study echoes the findings from other studies focusing on the important characteristics of the program managers: 1) program manger's beliefs about students' funds of knowledge (e.g. Velez-Ibariez, and Greenberg, 2005), 2) skills to use the knowledge for more productive ways such as promoting cooperative learning environments (e.g. Roseth et al., 2008), and 3) skills to build strong human relationships between participants and program manager-youth participants (e.g. Dubois and Neville, 1997; Styles and Morrow, 1992). Particularly, most urban youth growing up in poverty, do not receive quality science education resource from quality schooling, afterschool programs, and science based out-of-school programs (Benard, 1992). Program managers not only serve as an important role model as a science teacher or scientist, but they also have a great potential to influence youth from poverty to enter into STEM careers through their attitudes, encouragement, expectations, resources, teaching methods, and classroom materials (Fadigan and Hammrich, 2004).

This study also implies that program missions and institutional support for informal science education programs is important for youth in poverty to develop their identity as active social members. In most cultures, youths' role as active social members is ambiguous in terms of their right to participate in decisions for the society and their actual contributions to the society. Kurth-Schai (1988) argues that the underestimation of youth ability as inactive members of society is the result of the current legal and education system, in which the major task of youth is academic achievement, not participation in socially approved productive work or important decision making in their community. Because of the school's definition of the success of youth development such as success of academic achievement, youth struggle with 'conflicting perceptions of their abilities and inadequacies, rendering their social presence inconsequential and their social power invisible' (Kurth-Schai, 1988, p 116). As this study shows, the program's mission and institutional support to hire youth in poverty as paid museum staff is very important in making the youth responsible for their tasks and building their social identity. Every student needs to experience success in their school and work place. Through program managers and institutional support, the experience of being successful as an active social member could be possible for youth in poverty.

\section{References}

Atwater, M., 1995, The multicultural science classroom, part III: Preparing science teachers to meet the challenges of multicultural education. The Science Teacher, 62, 26-29.

Baum, L., Hein, G.E., and Solvay, M., 2000, In their own words: Voices of teens in Museums. Journal of Museum Education, 25, 9-13.

Beane, D.B., 2000, Museum and healthy adolescent development: What we are learning from research and practice. Journal of Museum Education, 25, 3-8.

Benard, B., 1992, Mentoring programs for urban youth: Handle with care. Department of Education, Washington DC, USA, $30 \mathrm{p}$.

Dierking, L.D., 2007, Linking after-school programs and STEM learning: A view from another window. Retrieved from htp://www.afterschoolscience.org/pdf/ member_publications/Linking\%20After-School\%20Programs \%20and\%20STEM\%20Learning.pdf (May 20th 2010)

DuBois, D.L. and Neville, H.A., 1997, Youth mentoring: Investigation of relationship characteristics and perceived benefits. Journal of Community Psychology, 25, 227-234. 
Fadigan, K.A. and Hammrich, P.L., 2004, A longitudinal study of the educational and career trajectories of female participants of an urban informal science education program. Journal of Research in Science Teaching, 41, 835-860.

Falk, J.H., Storksdieck, M., and Dierking, L.D., 2007, Investigating public science interest and understanding: Evidence for the importance of free-choice learning. Public Understanding of Science, 16, 455-466.

Fusco, D., 2001, Creating relevant science through urban planning and gardening. Journal of Research in Science Teaching, 38, 860-877.

Gess-Newsome, J. and Southerland, S.A., 2000, Teaching science for all. In Wade, S.E. (ed.), Preparing teachers for inclusive education: Case pedagogies and curricula for teacher educators. Lawrence Erlbaum Associates, Mahwah, USA, 81-106.

Gonzalez, N., 2005, Beyond culture: The hybridity of funds of knowledge. In Gonzalez, N., Moll, L., and Amanti, C. (eds.), Funds of knowledge: Theorizing practices in households, communities, and classrooms. Lawrence Earlbaum Associates, Mahwah, NJ, USA, 2946.

Nelson, A.G. and Schreiber, R.C., 2009, Participatory Evaluation: A Case Study of Involving Stakeholders in the Evaluation Process. Visitor Studies, 12, 199-213.

Hammond, L., 2001, Notes from California: An anthropological approach to urban science education for language minority families. Journal of Research in Science Teaching, 38, 983-999.

Jung, W-J., Lee, J-Y., Park, E-J., Kim, C- J., and Lee, SK., 2009, Interaction patterns in dialogic inquiry of middle school students in small groups in the natural history gallery. Journal of Korean Earth Science Society, 30, 909-920.

Jung, N-S., Woo, J-O., and Jeong, J-W, 1995, Analysis of frameworks on astronomic conceptions in secondary school students. Journal of Korean Earth Science Society, 16, 188-193.

Kim, K., Lee, S-K., and Kim, C-J., 2009, Characteristics of children's interactive learning in a natural history museum. Journal of Korean Earth Science Society, 30, 127-140.

King, K., Shumow, L., and Lietz, S., 2001, Science education in an urban elementary school: Case studies of teacher beliefs and classroom practices. Science Educa- tion, 85, 89-110.

Koke, J. and Dierking, L., 2007, Museums and libraries engaging America's youth: Final report of a study of IMLS youth programs, 1998-2003. Institute of Museum and Library Services, Washington, DC, USA, 139 p.

Kurth-Schai, R., 1988, The roles of youth in society: A reconceptualization. The Educational Forum, 52, 117132.

Ladson-Billings, G., 1995, Toward a theory of culturally relevant pedagogy. American Educational Research Journal, 32, 465-491.

Larson, R.W., 2000, Toward a Psychology of Positive Youth Development. American Psychologist, 55, 170183.

Merriam, S.B., 1998, Qualitative research and case study applications in education. Jossey-Bass, San Francisco, USA, $275 \mathrm{p}$.

Miles, M.B. and Huberman, A.M., 1994, Qualitative data analysis: An expanded sourcebook. Sage, Thousands Oaks, USA, 338 p.

Murrell, P.C., 2000, Community teachers: A conceptual framework for preparing exemplary urban teachers. The Journal of Negro Education, 69, 338-348.

Resnick, L.B., 1987, Learning in school and out. Educational Researcher, 16, 13-20.

Roseth, C.J., Johnson, D.W., and Johnson, R.T., 2008, Promoting early adolescents' achievement and peer relationships: The effects of cooperative, competitive, and individualistic goal structures. Psychological Bulletin, 134, 223-246.

Sleeter, C.E., 2001, Preparing teachers for culturally diverse schools: Research and the overwhelming presence of whiteness. Journal of Teacher Education, 52, 94-106.

Styles, M.B. and Morrow, K.V., 1992, Understanding how youth and elders form relationships: A study of four linking lifetimes programs. Temple University, Philadelphia, USA, $102 \mathrm{p}$.

Velez-Ibariez, C. and Greenberg, J., 2005, Formation and transformation of funds of knowledge. In Gonzalez, N., Moll, L.C. and Amanti, C. (eds.), Funds of knowledge: Theorizing practices in households, communities, and classrooms. Lawrence Erlbaum, NY, USA, 47-69.

Villegas, A.M. and Lucas, T., 2002, Preparing culturally responsive teachers: Rethinking the curriculum. Journal of Teacher Education, 53, 20-32. 